\section{Effects of Women Representation in Advertising on Customers' Attitudes}

\author{
Jelena Stanković, Radmila Živković, \\ Tamara Marić, Jelena Gajić
}

JEL Classification: M37

\section{THE EFFECT OF ADVERTISEMENTS ON CONSUMERS' ATTITUDES}

The role of advertising in a contemporary society has been a subject of numerous debates. Not only does advertising stimulate purchasing of products and use of services (Moriarty, Mitchell, Wells, 2009, 58; Ognjanov, 2009, 151), but it also contributes to the consumers' formation of social identity, frequently, influencing both their current attitudes and what they should be (Gallagher, 2016, 24; Maričić i Radulović, 2013,5).

Modern consumers are exposed to a great number of advertising messages on a daily basis, as a result of which they quickly react by buying. This is indicative of the probability that such contents are socially acceptable and are a reflection of modern consumer culture (Pardun, 2013, 3, Maričić i Radulović, 2013, 5). Let us take the following situation into consideration - on his way back home from work, a consumer passes by three billboards showing advertisements for Volkswagen cars, to which he pays no attention. When he comes home, while watching the news online, he notices a Volkswagen ad in the right hand corner of the web page he is on. A logical question that arises is whether Volkswagen is spending their money in vain. According to Robert Heath, an influential academic and researcher from England, the money is not frittered away in such case. In his book The Hidden Power of Advertising (Heath, 2011), he points out that the influence of advertising is not limited to the depth of message or to the consumer's power to process a rational and emotional message, but is also manifested through the process of low inclusion of the consumer. Prior to this theory, it was assumed that advertising had an influence only after consumers had paid close attention to a particular advertisement, or if they had had even the slightest awareness of having seen an ad. Heath emphasizes that advertising has an effect regardless of whether we are aware of that or not (Heath, 2011). Every time we see an advertisement, it has an impact on our consciousness or subconsciousness (Belch and Belch, 2013, 18; Maričić i Radulović, 2013, 21). Furthermore, Heath explains that advertising influences the formation of permanent association in human consciousness, although we may not be aware of that. These associations are upgraded in time, changing the con-
Abstract: The influence of advertising on creating social attitudes and customer behavior is visible both on rational and emotional level. Due to that, advertising creates psychological effects, and is also in conflict with moral and ethical standards of the society which should be based upon. Stereotypical representation of women in advertising, which usually includes images of a housewife, business woman with no family, or just an ornament, can be found in all kinds of ads, such as TV and Internet commercials, billboards, on a daily basis. However, the paradox which women very often face, with no clear connection with the product or service which is been advertised, brings up the following questions as the purpose of this paper: whether frequent representation of women in advertisements is necessary, or desirable even, whether the suggested models of women's beauty which is promoted in this way, are the most powerful 'means' for sales. If it is the most powerful means, is it possible to settle two opposing phenomena that arise from such a fact - the social one, which puts a woman in a negative context, has a negative effect on her personal satisfaction and self-confidence, and is opposed to the morals and ethics, and the marketing one, which has an aim of attracting consumers, thus changing their attitudes towards purchasing.

Key words: advertising, women in ads, customers' attitudes, ethical issues. 
sumers' behavior and prompting him to switch from using one brand to using another one. In psychology, such an effect is called the mere-exposure effect and it is a phenomenon by which people develop a preference for things merely because they are familiar with them (Ferrier and Fleming, 2014, 27). In other words, the more familiar consumer with a brand, the more he will like it. In addition, he may not be aware of the advertising message of the brand in question.

The impact of advertising is frequently so strong that buyers lose a personal feeling for critical thinking and clear perception of things (Hayko, 2010, 79). Therefore, it can be concluded that advertising to a great extent fosters and supports the development of consumer society and the materialism culture, which is particularly characterized by valuing acquiring of and exhibiting one's property, as well as an aspiration to a lifestyle that involves having material possessions (Belch and Belch, 2012, 688), without sharing them. Moreover, having valuable possessions does not contribute to greater happiness, but only leads to new living demands that a particular person makes, and which does not result in great satisfaction with their lives (Kanuk and Shiffman, 2004, 105). The criticism of advertising is centered, above all, on a particular person's replacing inner motivation and happiness with a new social role, which boils down to buying and the consumption of happiness. The researches have shown that by utilizing stereotypes and manipulating emotions and ideas of real life situations, advertising has rendered a modern consumer rather economically irrational human being (Belch, Belch, 2012, 688; Hayko, 2010, 80).

Luxury, lavish lifestyle, beauty and sex are frequently the contents of advertising strategies which promote a large number of products, from chocolate and cosmetics to cars and fashion (Aysad, 2014, 61296130; Arens. Weigold, Arens, 2011,47). Women showing their faces and bodies in ads, is another example of the influence of advertisements on the consumers' attitudes. Such influence is usually considered negative, with an argument to the effect that female body in ads is used as a sexual object, which inevitably devalues the role and value of women in society. Nevertheless, different attitudes also exist. Certain feminists from academic circles, support such a trend in its entirety, characterizing it as the use of bodies as works of art (Zimmerman and Dahlberg, 2008, 72). On the other hand, the act of women showing their faces and bodies in advertisements is used as a definition of beauty, which becomes a model of a kind, even an ideal which women strive for (Belch, Belch, 2012, 691, Berberick,
2010, 2). A negative side of such messages of 'ideal beauty' whose most common protagonist is a woman, can be seen in a fact that advertising has a power to influence consumers' perception of self, and cause problems such as unhealthy diet, depression and personal dissatisfaction (Hayko, 2010, 80). Such persuasive advertising contains numerous emotional appeals (Živković, 2011, 131-132) which in a cited example, created a series of negative feelings in a consumer, such as fear, a feeling of guilt, concern etc. These kinds of strategies have a powerful influence on adolescents, particularly young girls, who are in search of their identity. By buying a particular cosmetic product, they believe they will change themselves and become like a model from the advertisement.

Brands which trigger strong emotional reactions of consumers are evaluated to be generating better sales and profit, and have a greater level of credibility among competitors (Filipović, 2014, 355; Moriarty, Mitchell, Wells, 2009, 57 Florin isar., 2009, 1). Also, advertisements which require emotional involvement and contain stimulation, are easier to remember by women more than by men (Baird, Walhers, and Cooper, 2007). Furthermore, women tend to have positive reactions to the messages of advertisements more than men. The use of emotional appeals can be effective in female consumers even in case of products, which by their nature, do not arouse any emotions, such as for example, car tires (Baird, Walhers, and Cooper, 2007).

A study has demonstrated that men have better reactions to advertisements aimed at their perception of self, whereas women react better to advertisements showing situations they are able to sympathize with (Brunel \& Nelson, 2003). Some studies have also reported that celebrities and typical kinds of people appearing in advertisements also draw women's attention in an effective way (Cramphorn, 2011).

\section{THE ROLE OF WOMEN IN MODERN ADVERTISING MESSAGES}

It can be asserted that advertising sells values, images and concepts of what is considered to be normal. Through perfectly set images, advertisers strive to create a virtual reality and impose the idea of what is considered normal in society in its entirety. Author Jim Fowles defined changing fashion trends as a cycle of attraction, and pointed out that the cycle has been defined in popular culture and completed in advertisements (Klein, 2013, 30). The evolution of the role of women in the cycle of attraction clearly indicates the 
changes in style, fashion and social values. Through idealized images, advertising tells consumers who they are and who they wish to be. Through manipulation of words and messages, advertising influences the consumer's critical power of reasoning. In this way, it creates an unhealthy environment for a woman's self-confidence. Such environment prompts women's dissatisfaction with their own bodies, which usually leads to an obsessive control of their basic need for food (Klein, 2013, 30).

Women are most frequently, tendentiously portrayed as beautiful and attractive in commercials (Aysad, 2014, p. 6129), which is supposed to trigger in viewers and buyers, an association of what is aesthetically acceptable, the appearance which is preferred and which should be striven for. The female characters in commercials are usually given the role of objects of attraction, perfect housewives or independent young women (Nagi, 2014, p.86).

\section{Differences in representation of women and men in advertisements}

A study which analyzed the results of 30 different researches, has stressed the difference in representation of men and women in commercials by four different criteria (Furnham and Paltzer, 2010, pp.217-218). According to the first criterion, conveying a verbal vs. conveying a visual message, the study has shown that the role of men is more dominant in conveying a verbal message, whereas women were predominantly given a visual role in commercials.

Credentials, as another important criterion, was analyzed from the aspect of expert vs. user, which men or women could assume in commercials (Furnham and Paltzer, 2010, 217-218). In the majority of European countries, women were predominantly represented as users of products which were being advertised. However, when it comes to men, both the roles of users and authorities (experts) were equally evident. In other words, $42.9 \%$ of men were portrayed in the role of a product user, while in $38.1 \%$ cases, they were represented as experts. The only exception to the rule was Russia, where men assumed the role of product users in more cases than women (Furnham and Paltzer, 2010, 217-218).

Studies which were conducted in Europe have found considerable differences in the engagement of protagonists from certain age groups in commercials (Furnham and Paltzer, 2010, 217-218). The most common protagonists of commercials were young women (60\%) in Russia, Turkey, Sweden, Poland, Bulgaria and Asia, while, in Austria, for example, commercials featured $64.1 \%$ of middle-aged men.

Another category which was analyzed in the studies was the way in which advertising represented awards consumers would earn if they bought a particular brand, depending on their gender. When talking about Europe, in Poland rewarding women was mainly demonstrated in the form of gaining a better position in society and self-affirmation, which occurred in $37.7 \%$ of cases, which is double the percentage of the segment of men. In Turkey, this ratio was $44.4 \%$ for women, compared to $16.1 \%$ of men. Concrete and practical rewards are promoted via commercials to women in Serbia (65.8\%), while satisfaction with oneself and with what one could achieve by the consumption of a product is promoted to men (45.9\%) (Furnham and Paltzer, 2010, 219-220).

In order to gain a better insight into the differences of representation of men and women in commercials, it is necessary to analyze their body language. Men are usually portrayed in laid-back manners, with an attitude of dominance, legs spread apart, looking straight into the camera (picture 1, left), illustrating the concept of masculinity, which implies rationality and self-confidence to the viewer. On the other hand, women are usually represented in commercials sitting or standing, legs crossed, arms resting on their bodies (picture 1, right), which send the message of
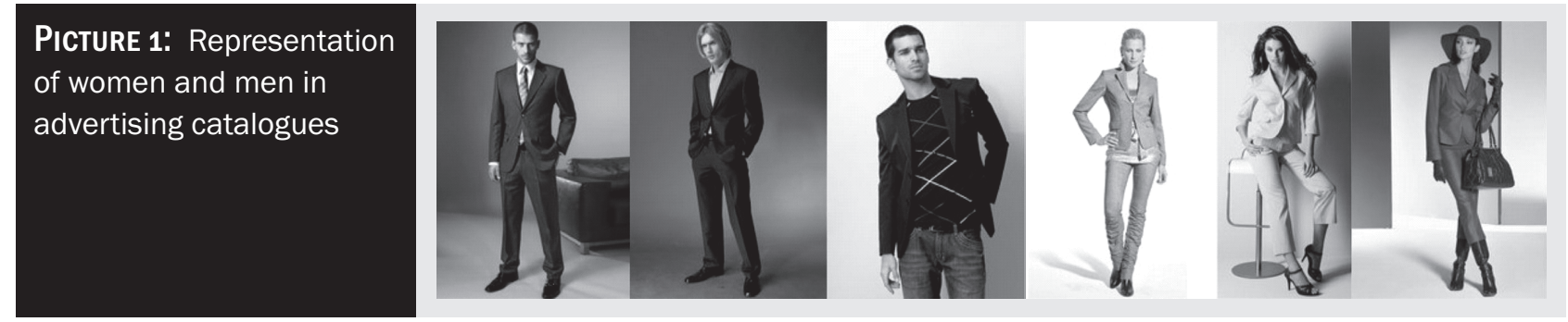

Source: FemCities Conference (2012) Ending Gender Stereotyping and Sexist Portrayals in Advertising, City of Vienna, Department for the Promotion and Coordination of Women's Issues, p. 10. 
their emotionality, sub-ordinance even, to the viewer (FemCities Conference, 2012, 10).

Facial expressions of women in commercials are far more emotional compared to men. Such stereotypical portrayal stems from a traditional assignment of subordinate role to women as housewives, who are not independent and have no freedom. The same goes for men in commercials, who display an attitude of dominance in family and society. The situation, has, to a certain extended, changed, especially, owing to the increase of the number of women on the job market (Sheehan, 2014, 89). Researchers report that in modern advertising campaigns, contrary to representations of men as being occupied with work, working women are usually depicted as being occupied with themselves and their own bodies, rather than their jobs (Catalogue of Criteria for the Classification of Sexist Advertising, p. 5, retrieved from: http://www.werbewatchgroup-wien.at/, 10.08.2017).

\section{Women as (sexual) objects in commercials}

Messages with sexual contents are relayed not only through images, but also by way of words which accompany them. Advertisers link such messages to the brands they promote. When it comes to commercials with sexual connotations, three brand promises can be singled out (Aysad, 2014, 6131-6132):

- Sexual attraction promise - this promise can frequently be found in perfume commercials, the main role played by a woman who enters a room filled with people who watch her with amusement, while a handsome man follows her through the crowd.

- More frequent sexual intimacy and enjoyment promise - such examples are frequent in commercials for cosmetic products for body care, such as lotions and shower gels in which a man expresses overwhelming desire to touch 'velvety' woman's skin thanks to her usage of a particular cosmetic preparation.

- A promise that a consumer would feel more sexually appealing - just like the previous brand promise, this one is also typical of commercials in the cosmetic industry which by showing attractive famous women, consumers are sent the message that they would attain a sexually appealing look of the model represented in the commercial if they used a particular product.

The world's leading brands such as Victoria's Secret, Calvin Klein, Giorgo Armani, Nike, Gucci, have defined their identities at the same time defining sexual identities of women (Torlak, 2013, 38). Upon analyzing the role a sexual appeal can have in the field of modern marketing, it can be concluded that people resort to its usage due to the fact that erotic motives according to a number people's views represent something that attracts their attention. This reason has an entirely psychological background, due to the fact that sexual desire holds for second instinctive urge in intensity, immediately after the urge for self-protection which is always present in person (Torlak, 2013, 38; Filipović, 2013, 357). In order for a sexual appeal to be effective, advertisers need to make sure that the product, commercial, aim, consumers and deployed sexual contents are carefully coordinated (Nagi, 2014, 75).

The manner in which women are represented in commercials in women's magazines considerably differs from the way of their representation in commercials in men's magazines. On the one hand, advertisers primarily focus on the product, and less so on the model itself in women's magazines, whereas, the woman's body is the most important element of a commercial in men's magazines. Women are aimed at by the commercial in women's magazines, while, women serve as an advertising material in men's magazines. Actually, products are advertised in women's magazines in order for a target group to purchase them, while woman's body is principal in viewers' eyes in men's magazines. In commercials published in men's magazines, woman's face and body are used as a means of marketing the message on product.

Picture 2 depicts a commercial for the Wolverine men's boots. An attractive blonde woman states: 'I am

\section{PICTURE 2: Commercial for Wolverine} boots and MAX shoes

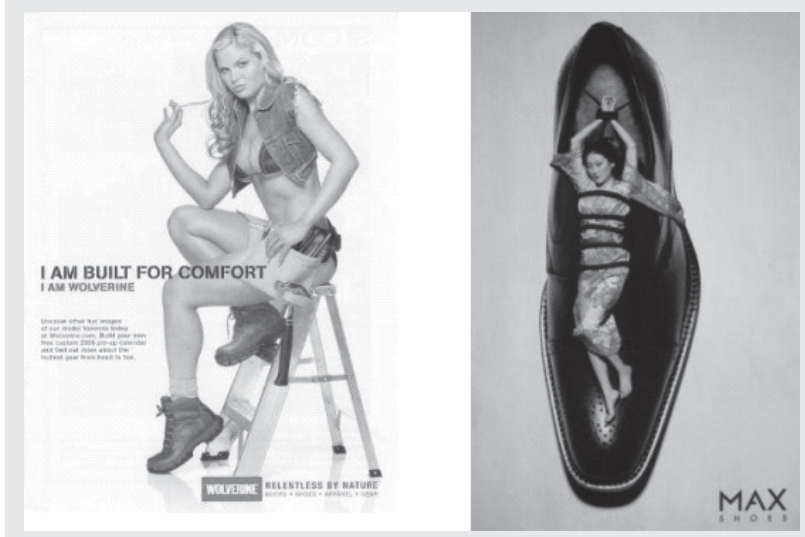

Source: Crisan, R., Pop, A. (2013) Women as Advertising Target Versus Women as an Advertising Tool, Academica Science Journal, Economica Series, No. 2 (3), p. 11. 
built for comfort. I am Wolverine.' (Crisan and Pop, $2013,11)$. The use of verb 'built' leaves an impression that it is the matter of an object, and not a human being. A verbal message of this commercial is that woman's body is an object, which was specially made for men's usage. Picture 2, right, shows a commercial for MAX shoes, in which a woman is depicted in a subordinate position, sexually accessible, since she is not able to resist. She is tied to a shoe, and her passive 'slave-like' position, entirely excludes an aspect of her personality, because the non-verbal message is clear - a woman is accessible, exclusively for a man's usage (Crisan and Pop, 2013, 11).

The fact is that eroticism in advertising messages can have a positive persuasive role for their target group, in both men and women, as long as it is kept within acceptable limits (Crisan and Pop, 2013, 14).

\section{Differences in advertisements' perception by women and men}

Studies performed on the sample of 100 final-year undergraduate students of both genders have shown that men and women share certain similarities, but they also show differences in the perception of sexual contents in commercials (Torlak, 2010, 56). Final-year female students recognized sexual appeals in the way of representation of women to a greater extent (28\%) compared to male portion of the student population (6\%). Contrariwise, men described physical characteristics of models (e.g. physical beauty, body and type of clothes) in more detail than women. Nevertheless, although men provided such description to a greater extent (71\%), women, too, found physical features important (58\%). Models' movements and other non-verbal behavior were also important for both women (37\%) and men (37\%). These studies demonstrate that men and women have different reactions to sexual stimuli, meaning that the respondents' gender has a significant influence on the perception of sexual contents of advertising messages (Torlak, 2010, 56). It is also interesting to note that men and women react to commercials with sports contents in a different way. Women rarely consider themselves sportswomen, except for in cases when they play professional sports, whereas, men perceive themselves to be sportsmen, even if they do not do professional sports (Sheehan, 2014, 91).

Practice has shown that sexual appeals have a stronger persuasive influence on men than they do on women (Sheehan, 2014, 104). One of the reasons why this is so is that men, traditionally speaking, consid- er women who are young, healthy and beautiful to be good partners. Therefore, visual messages (pictures) are used in commercials in order to attract men's attention, who will link the purchase of a product to winning a woman's heart on a subconscious level. On the other hand, women pay more attention to the long-term potentials of men - their capabilities of becoming a father, making money and having power and prestige. Since it is almost impossible to represent all these factors in one place, commercials aimed at women use a romantic appeal and show courting, relationships and the process of falling in love. It can be concluded that visual elements of commercials (picture) aimed at women are more focused on an intellectual than physical aspect (Sheehan, 2014, 104).

Depending on the perception of an advertising message, men and women make decisions about purchase (Sheehan, 2014, 91). Men process messages and make decisions much faster than women, one of the main reasons for it being their exclusive concentration on the primary message, whereby their way of reasoning can be considered linear (Sheehan, 2014, 91). On the other hand, women process information from different sources and at different levels, including music, images, sounds and text. The process of making decisions in women happens in such a way that every new piece of information is an upgrade of the preceding one. Such non-linear way of reasoning enables women to think about closely related factors (Sheehan, 2014, 91).

\section{Analysis of examples of representation of women in advertisements of famous brands}

\section{- Coca Cola advertisement for the Fairlife milk}

The advertising campaign of the Coca Cola company for new milk was met with sharp criticism by the public due to the prevailing sexual appeal in the way women were represented. Women were shown naked with only parts of their bodies covered in milk in the commercials (picture 3). This campaign was inspired, apart from a well-known catchphrase that 'sex sells', by Coca-Cola's previous commercials from the time the so-called pin-up girls like Marilyn Monroe were popular (Klauster, 2014, Bad taste? Coca-Cola under fire for , sexist' new ad campaign which features naked women covered in dripping milk, retrieved from: http://www.dailymail.co.uk/, 04.07.2016).

Advertising slogans used in these commercials were: 'Drink what she's wearing' and 'Better milk looks good on you'. This advertisement is an indicator 
Picture 3: Advertising slogans of the Fairlife campaign

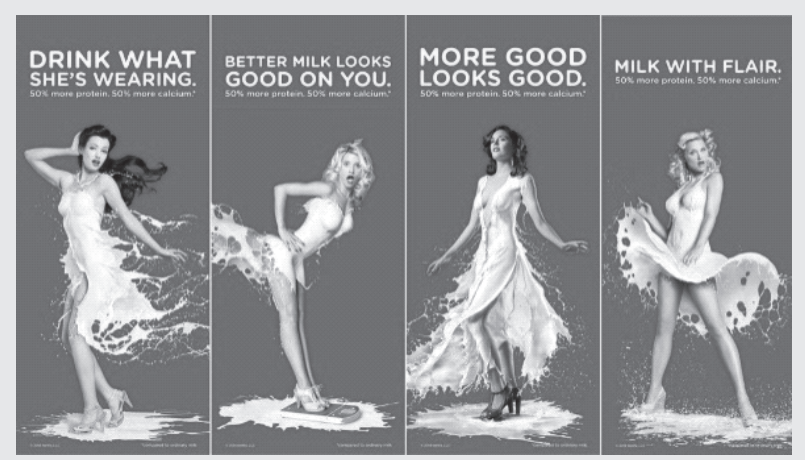

SouRcE: http://www.eonline.com/news/602804/cocacola-s-sexist-milk-ads-won-t-be-used-for-their-nationalcampaign-following-backlash, retrieved: 04.07.2016.

of stereotypical representation of a woman as a sexual object in the media advertising, in addition, the product offered in such manner cannot be connected to a woman (Fairlife's new milk adverts are unoriginal and tediously sexist, retrieved from: https://www.theguardian.com/, 04.07.2016). This campaign caused strong reaction of consumers on Twitter, who vehemently condemned it and labeled it as a way of promoting sexual objectification of women (Carey, 2014, Coca-Cola Under Fire For Fairlife Ad Campaign Featuring Nude Women Draped In Milk, retrieved from: http://www.business2community.com/, 04.07.2016).

- Advertising campaign of the Belgian organ donor foundation

The campaign of the Belgian organ donor foundation with the slogan of 'Becoming a donor is probably your only chance to get inside her' provoked extreme public reaction, considering that sexual appeal was used to promote humanitarian effort of organ donations. The commercial showed a young, lean woman in underwear and high heels (picture 4). The objectification of a woman, via humanitarian message, downplays her role, reducing her to being nothing more than a sexual object. The commercial can, at the same time, be offensive to men as well, by sending the message that they are superficial beings whom only sex can motivate to do a good deed.

The logo and slogan of this commercial was removed from the www.adwomen.org website, and visitors were asked a question of what, in their opinion, the commercial promoted. Some of the answers provided were organ donations, underwear and shoes. Out of 755 visitors who answered the question, $42 \%$
Picture 4: Campaign of the Belgian

organ donor foundation

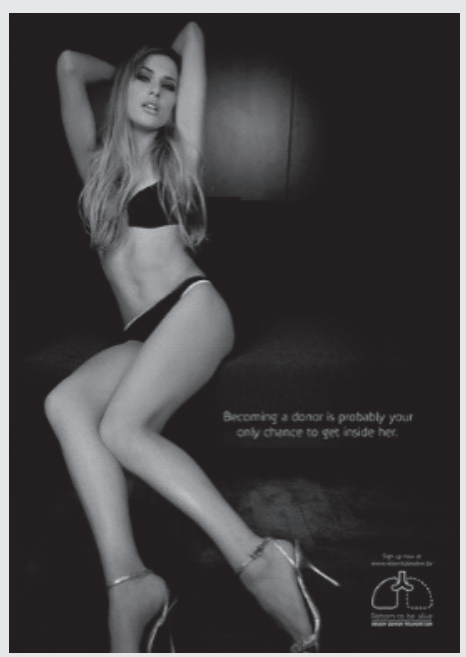

SouRcE: http://www.adwomen.org/2011/06/what-is-thisad-announcing/, retrieved: 08.08.2017.

(318 visitors) suggested it was organ donation, 30\% (227 visitors) thought it was the underwear commercial, while $28 \%$ (210 visitors) considered it to be the shoe ad (http://www.adwomen.org/2011/06/whatis-this-ad-announcing/, retrieved: 08.08.2017). Respondent who answered correctly can be assumed to have seen the advertisement earlier, which is the reason why they provided a correct answer. The results of the survey, besides danger of sexual objectification of women, point to a potential problem of misleading consumers, especially if they find it hard to make a connection between the purpose and the subject of the advertisement.

\section{- Sony PlayStation Vita Advertisement}

The 2011 advertisement promoting the Sony hand console with precise dual analogue controls and installed memory, portrayed a faceless woman with two pairs of breasts, to the front and back (picture 5). This ad was targeted at teenagers and young men with the slogan 'Touch both sides for added enjoyment' representing a woman's body as a part of play and an object that serves for touching (http://www.eurogamer. net/articles/2012-11-01-sony-ad-compares-playstation-vita-to-a-woman-with-four-breasts, retrieved: 08.08.2017).

Sony PlayStation is a company that frequently uses sexual appeals in its ads, owing to the fact that their target group is mainly teenagers and young men who are most susceptible to such influence. Nonetheless, 


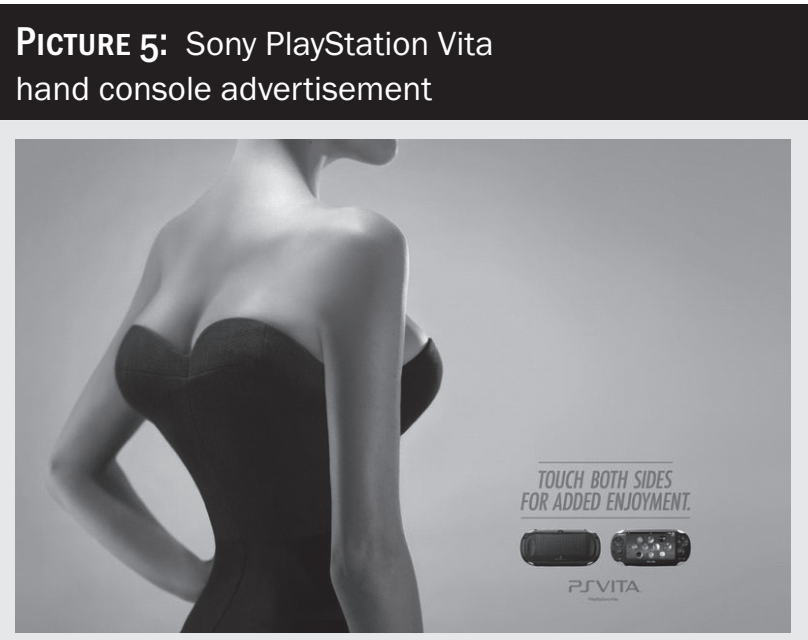

SOURCE: https://adsoftheworld.com/media/print/ playstation_touch_both_sides, retrieved: 08.08.2017.

assuming that an ad is a reflection of a company's values and its brand, the question that arises is whether the subconscious message of the company is that women are seen as games, that can be controlled and manipulated. Due to the fact that such ads are strongly criticized in public, they threaten to tarnish the image of the company in the long-term, which can have a negative effect on the company's overall business.

- The BMW campaign g 'Ultimate attraction'

The advertising of the BMW company entitled 'Ultimate attraction', in addition to the sexual appeal, also contains a stereotypical representation of sexes (picture 6). The ad depicts a man and woman during sexual intercourse, with woman's face covered with the magazine showing the BMW car commercial (https:// adstrategy.wordpress.com/2010/03/18/bmws-ultimate-attraction/, retrieved: 10.07.2016). The magazine placed over woman's face, is an act of complete dehumanization, in which a woman has completely lost her identity, since her face has been replaced with the picture of a car in the magazine.

This commercial conveys a false image to the public about the relations between sexes. The body positions of a man and woman reflect a stereotype that men are dominant and control every situation, while women are subordinate and replaceable. The man is also distanced from a woman, whereas she looks as if she is trying to have him touch her at all costs (Kimmel, Hearn \& Connell, 2005, 37-38). It can be stated that the ad is also in a certain way offensive to men as well, as it depicts them as being superficial, not interested in having relationships with women, and ob-
PIcTURE 6: The BMW campaign 'Ultimate attraction'

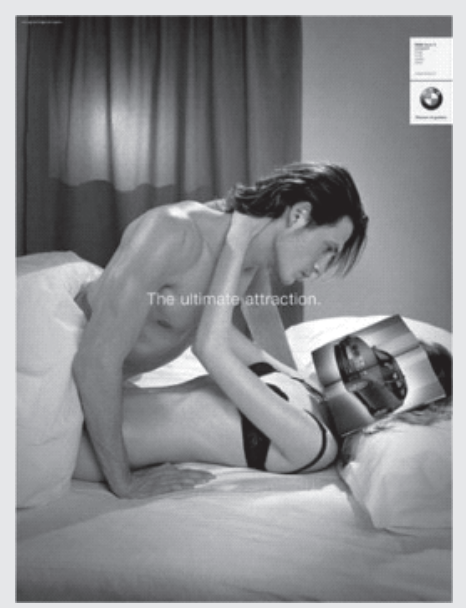

SouRcE: https://adstrategy.wordpress.com/2010/03/18/ bmws-ultimate-attraction/, retrieved: 10.07.2016.

sessed with material things such as BMW cars. The ad also sends the message that a man, if he purchases BMW cars, will be more attractive and win a beautiful woman's heart. Men relate to a man in the ad in their aspiration to identify with him, while the picture of a man and woman in the ad is far from being realistic (http://www.karanovic.org/courses/mca008/ archives/1515, retrieved: 10.07.2016). 'The Ultimate Attraction' refers to a passionate relationship between a man and woman, since the woman in this imagery is practically non-existent. The only attraction that exists is the one between a man and car.

The social role of advertisements in the life of women is depicting them but also forming them. This type of its power should be used in an ethical way, through planning of extremely realistic representation of women. Studies have shown that realistic representation in ads leave a positive impression on consumers, whereas, certain types of representations including objectification of womenapart from other things, provoke negative reactions by consumers (Sheehan, 2014, 108).

- Realistic representation of women in advertisements

The Vogue fashion magazine launched an initiative in June 2012 to promote healthy look in advertisements. Being 'an ambassador of healthy representation', it would not use models who suffer from eating disorders in their ads, nor models younger than 16 on the pages of its editorial in its 19 international editions (Sheehan, 2014, 108). Ben Barry, a Canadian fashion 
agency founder, conducted a research about the extent to which representation of women in advertisements had an impact on their decision to buy (Sheehan, 2014, 108). The results have shown that women relate to ads to a greater extend when models wore their actual size, were of their age and had the same skin color. This has only confirmed the results of an earlier study which demonstrated that the majority of women consumers wanted to see models with natural body shapes in magazines (Sheehan, 2014, 108).

The majority of women in the study stated an intention of buying magazines showing 'plus-size' models, although they had taken a stance that clothes looked better on leaner models (Sheehan, 2014, 108).

The habits of behavior of the Y generation point to their surfeit of perfection in the consumer society. The fact that \#nofilter hashtag denoting that the photographs are real and untouched, is one of the most popular hashtags on Instagram, testifies to that. In a survey from $2014,86 \%$ of members of this generation has stated that flaws made people more authentic, while $63 \%$ reported they liked buying goods with defects (Bergh, V. J., 2014, Trends for 2015: Perfectly Imperfect, retrieved from: http://www.howcoolbrandsstayhot.com/, 06.07.2016). The Diesel brand expressed a support of imperfections in its advertising messages, within its campaign \#DIESELREBOOT (picture 7), with one of the ads featuring Jillian Mercado, a model in wheelchair suffering from muscle dystrophy (Bergh, V. J., 2014, Trends for 2015: Perfectly Imperfect, retrieved from: http://www.howcoolbrandsstayhot. $\mathrm{com} /$, 06.07.2016).

\section{PICTURE 7: \#DIESELREBOOT Diesel campaign}

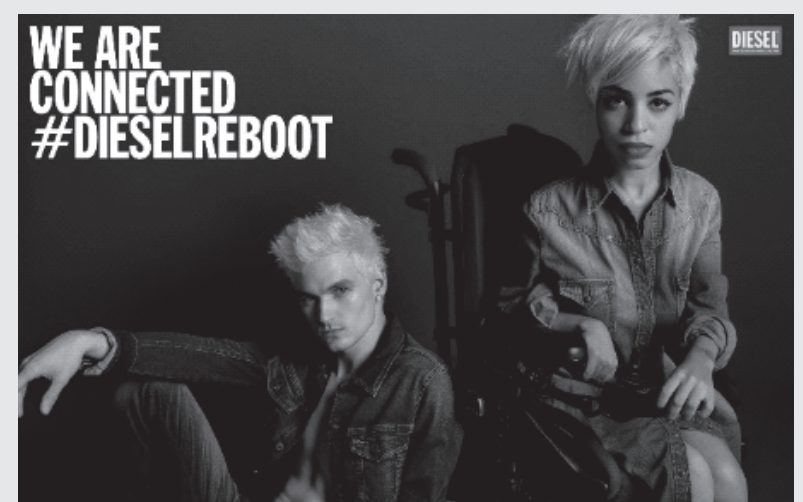

SOURCE: http://www.nicolaformichetti.com/diesel-ss-2014campaign-dieselreboot/, retrieved: 06.07.2016.
American Eagle did a similar thing in its campaign American Eagle I'mperfect, in which it mounted resistance to the 'one-size-fits-all' concept of beauty, embraced by a number of fashion brands. The idea of this company was to establish democracy in the world of jeans, by launching 22 models in 84 different sizes that would fit every person and character. The campaign was launched through printed advertisements, posters, digital videos and short commercial with the slogan 'My Imperfections Make a Perfect Me', as well as though a powerful imperfect brand declaration (Picture 1) (http://news.wearetranslation.com/translation-delivers-perfectly-imperfect-campaign-for-american-eagle-outfitters/, retrieved: 06.07.2016).

When talking about sexually explicit messages, with the aim of protecting their consumers, Facebook made a considerable step with their advertising policy which prohibits both showing people in sexually explicit and lascivious positions, and activities that are too intrusive or sexually provocative. The pictures may not depict nudity, nude skin or décolletage, or unnecessarily uncovering certain parts of the body even for the artistic or educational purposes. A similar improvement was made with regard to showing 'before and after' pictures, or photos containing unexpected or unreal results from using an advertised product (https://www.facebook.com/policies/ads/, retrieved: 06.07.2016).

The initiative by the American government non-profit organization 'About Face' aimed exclusively at fighting against distorted and bleak pictures of women in advertising messages is also interesting to note. Apart from numerous protests organized regarding sexually discriminating advertising messages, the movement got involved in spreading its network across the globe. They regularly publish 'The Hall of Shame' on their website, in other words, the list of producers who actually abuse women through the messages they send in advertising their products. The list of countries that have the greatest number of such commercials is also posted (France occupies the first position, while Serbia has not been on the list yet). Apart from that, the movement publishes addresses and phone numbers of such producers, together with letters of protest sent to the producers in question (Torlak, 2010, 112). 


\section{RESULT ANALYSIS OF THE RESEARCH ON THE INFLUENCE OF REPRESENTATION OF WOMEN IN ADVERTISEMENTS ON CONSUMERS' ATTITUDES}

The research carried out on the sample of 109 respondents of legal age, had an aim of observing attitudes of consumers in Serbia to representation of women in advertisements broadcast on TV, published in electronic media or the press. Out of the total number, $63 \%$ of respondents were females, while $37 \%$ were males. The research combined two types of surveys: a personal interview, comprising 20 respondents and 89 electronically via Facebook.

The research tested a hypothesis that modern ways in which women are used and represented in advertisements can create a negative image of women in society, from the aspects of their appearance, roles and values. Respondents, who took part in the survey, were also consumers who saw advertisements on a daily basis, through electronic media and the press.

The majority of respondents, i.e. $41 \%$, offered an affirmative answer to the question whether representation of women in advertisements left a positive impression on them. Additionally, as many as $30 \%$ of respondents replied they had no particular opinion, the reasons for it being both the advertising messages and the way in which they were conveyed. The next question had an aim of ascertaining in what ways consumers perceived types of women featured in commercials. As many as $92 \%$ of participants answered, that in their opinion, advertisements most frequently featured only one type of a woman - wearing full make-up and well-dressed, with perfect looks and complexion. Also, $82 \%$ of respondents provided a positive answer to the question whether they considered women featured in advertisements to be shown as decorative objects promoting an advertised product or service, in other words, they agreed with the assertion that women were used as decorative objects in ads, particularly in cases of product advertisements whose target group were men (e.g. car advertisements etc.). Only $8 \%$ had a differing viewpoint, while $10 \%$ had no particular attitude to the said question. Furthermore, the majority of respondents, i.e. $76 \%$ stated they considered that advertisements predominantly featured women without traces of old age on their faces, with consumers being sent the message that the model of youthful looks is preferred to the realistic portrayal of women. Only $11 \%$ of respondents had a different viewpoint, whereas $13 \%$ had no particular attitude.

When it comes to the question of whether women in ads were represented as a weaker sex, in other words, dependent on men, almost half the respondents held the view that women in ads were not depicted as dependent on men. Such results are not expected since the role of women in the $21^{\text {st }}$ century has evolved to a great extent, and in accordance with that, a need arose for the advertisements featuring them to be changed. Ads depicting successful business women who do jobs which were once only given to men exclusively are more and more frequent (Crisan and Pop, 2013, 15).

The majority of respondents, i.e. $46 \%$ answered positively to the question whether they thought advertisements respected women's dignity. As a part of a personal interview, respondents explained that women in ads were frequently represented in provocative positions compared to men, which, in their opinion, led to the creation of image of disrespect towards women. $15 \%$ of respondents answered negatively, while $39 \%$ were not able to define their viewpoints on the said question.

It is interesting to note that the majority of respondents, in this case $46 \%$, did not find it decisive to buy a certain product only because it was advertised by an attractive girl (graph 1). It is assumed that some other factors could be decisive in their making the decision, such as price and quality. On the other hand, as many as $74 \%$ of respondents were of the opinion that the feature of a beautiful and young girl in an ad would be a deciding factor in the decision to make purchase when it comes to other people, and not themselves (graph 2). Also, the majority of respondents, i.e. 82\%, expressed a view that an average woman - a woman from real life, did not correspond to the way a woman

\section{GRAPH 1: The influence of an advertisement}

featuring an attractive girl on one's

personal decision to make purchase

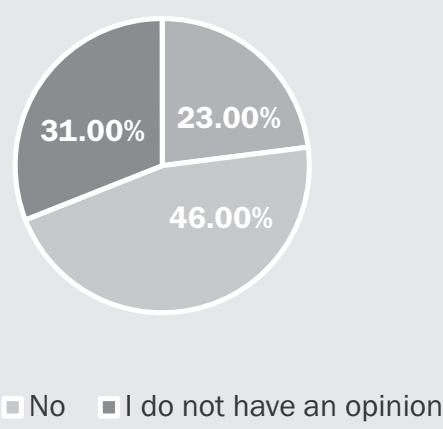


GRAPH 2: The influence of an advertisement featuring an attractive girl on the decision-making to make purchase on the part of other people

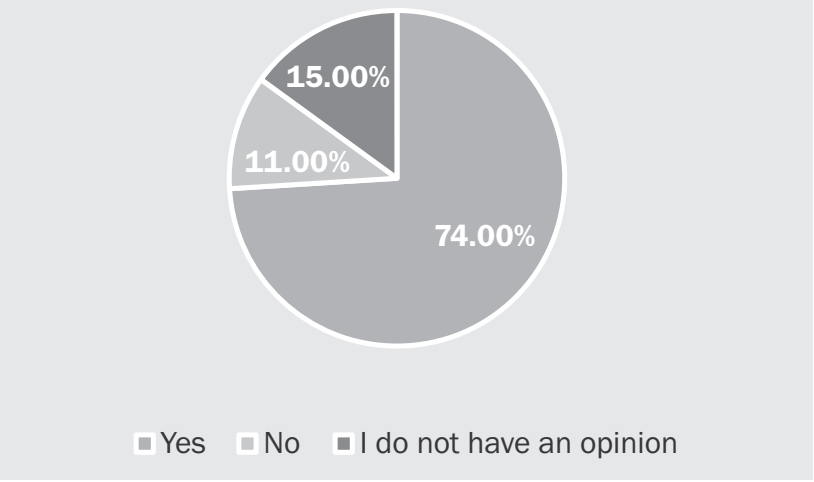

was depicted in advertisements (graph 3). Taking the data regarding answers to the said three questions into consideration, it can be concluded that: a) consumers were aware of unrealistic portrayal of women in advertisements $(82 \%), b)$ they had that in mind when making decision on buying (46\%), c) they were also aware of the fact that such an unrealistic, but attractive image, could be a decision-making factor in other consumers to make purchase.

As regards acceptability of showing a woman's nude body in advertisements, opinions differ. The acceptable option was selected by $27 \%$ of respondents, while $18 \%$ of respondents chose the partially acceptable option. On the other hand, the unacceptable option was selected by $29 \%$ of respondents, whereas $22 \%$ chose the partially unacceptable option. A greater number of respondents (51\%) selected options referring to the unacceptability of showing a naked woman's body in advertisements compared to the respondents choosing options referring to acceptability of such kinds of representations (45\%). It should be emphasized that

GRAPH 3: The respondents' opinion on the realism of portrayal of women in advertisements

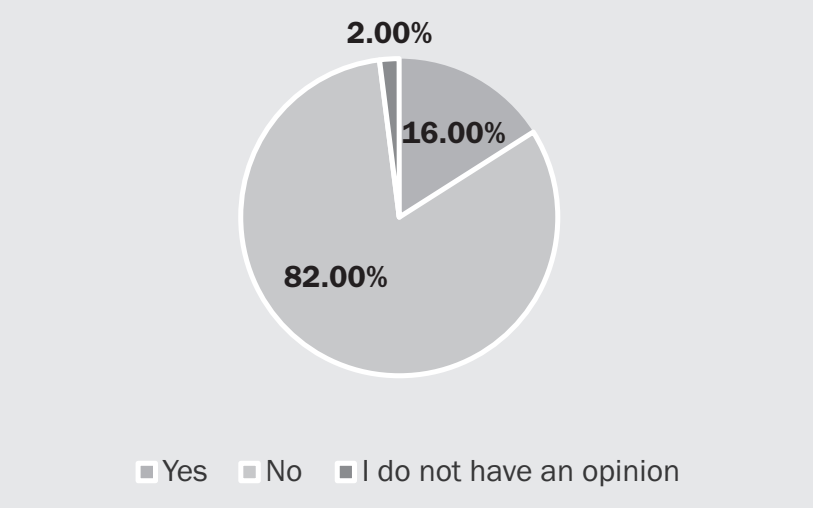

younger respondents were the ones who selected the acceptable option, while the unacceptable option was mainly chosen by the elderly. Such results may be expected, having in mind the fact that young people have almost unrestricted access to all kinds of contents, therefore, their understanding of what is acceptable and what not is different from the reasoning of the elderly section of society.

Also, the opinions on whether showing women's bodies in advertisements make women in real life insecure about their own bodies are mixed. Nevertheless, a somewhat greater number of respondents (44\%) took negative attitude to this issue, while $38 \%$ of respondents stated the opinion that naked woman's body could have an effect of women in real life feeling insecure concerning their attitude to their own bodies. It should also be stated that $18 \%$ of respondents had no opinion on the matter in question, which left room for researches relating to factors that impacted on their being undecided.

One of the questions posed referred to the attitude of respondents to the influence of representation of models of below average weight on consumers' attitudes (graph 4). The majority of respondents (57\%) voiced the opinion that advertisements promoting thinness as women's beauty ideal and featured famous models whose weight was below average, had a negative impact on women's attitudes in the real world. Advertisements with such contents had a significant effect on members of younger generation, teenage girls, who usually considered such models as beauty

\section{GRAPH 4: Respondents' opinions on the} influence of representation of models with below average weight on consumers' attitudes

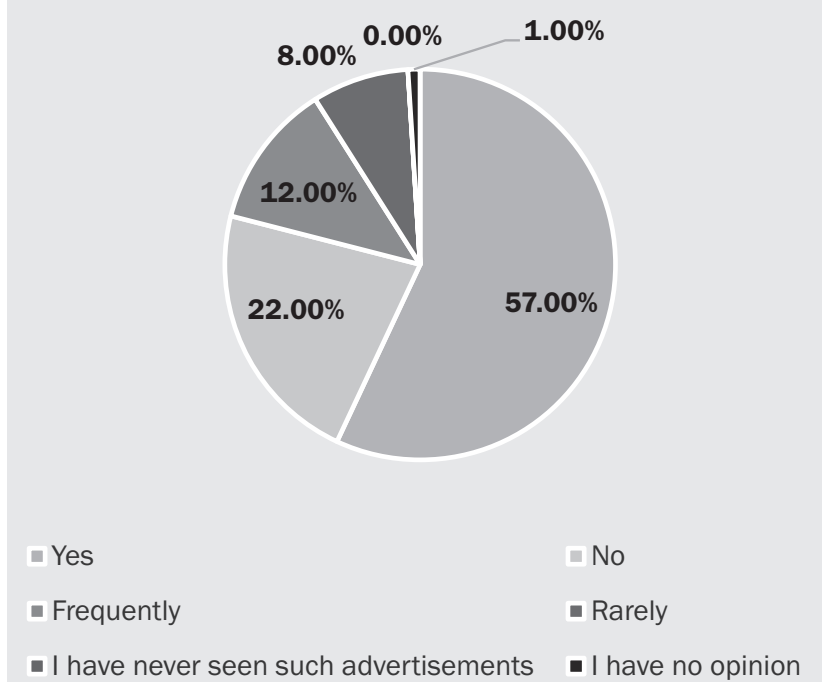


standards that should be striven for. Out of the overall number of respondents, 22\% thought such advertisements had no influence on women, while $12 \%$ of respondents expressed opinions that such advertisements had a negative effect on women.

Modern young women are becoming increasingly concerned with their weight, and this problem occurs as early as their childhood, at the age of nine. Advertising and mass media in general, seem to aggravate the problem even more due to the fact that young women are exposed to a great number of advertising messages insisting on them losing weight, on a daily basis. Having in mind that the media messages shape the formation of their social identity to a great extent, exposure of women to commercials that call for losing weight can have a significant effect on their habits and health concerning their diets (Hobbs, Broder, Pope and Rowe, 2006, 720). The influence of such advertisements on men is almost unnecessary for consideration, owing to the fact that men much less seek to buy dietary products, despite the fact that there is almost an equal percentage regarding weight problems i.e. $32.2 \%$ in men as opposed to $35.5 \%$ in women (Cawley, Avery, Eisenberg, 2011, 26). Models that are featured in advertisements have a perfect figure, which is a suggestion for a modern woman that if she wishes to be considered beautiful, she needs to look the way it was represented in an advertisement. Researches have shown that what women see in advertisements has an impact on their perception of their own bodies, and such occurrence has become more intensive in the last 20 years. Images of women have always been used to sell products, however, the problem arises the moment women consumers start to upload images of their lean bodies which were not edited in Photoshop, but are a result of exhausting diets that modern advertisements encourage them to go on (Klein, 2013, 12).

The majority of respondents, i.e. $56 \%$ of them, also think that advertisers should follow certain rules and guidelines when it comes to depicting women in advertisements, while $14 \%$ of them were of the opinion that it is even necessary to impose stringent rules (graph 5). There was a smaller number of those who thought censorship was not necessary and that advertisers should have a full freedom in creating advertisements (27\%).

The results of the conducted survey are in accordance with the results of researches that have been previously dealt with in the paper. Hypothesis that advertisements can create a negative image of women in society, which was analyzed many times in scien-
GRAPH 5: Respondents' opinion on existence

of rules and guidelines in the way women

are represented in advertisements

$3.00 \%$

$14.00 \%$

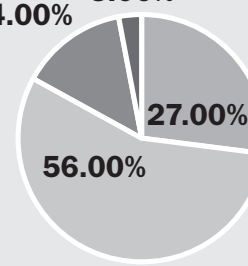

- Advertisers should have complete freedom

- There should be certain rules and guidelines

- There should be stringent rules

- I do not have an opinion

tific research and public discussions, was also proven within the framework of this primary research. However, the survey has certain limitations which should be emphasized and considered.

The limitation of the work primarily concerns the sample size and the sampling method used in the research. Namely, the used sample was very small and therefore, the validity of the conclusion should be taken with a caution. However, since it was more of a case study conducted as a pilot survey, and that the findings were more or less expected, the authors were encouraged to continue further research more extensively. That would involve a much larger number of respondents in order to make conclusions more relevant. The recommendation for future researcher concerns other demographic group (elder, children, ert.) that could be analyze and their impact on customers' attitudes as well.

However, the consumers' attitudes expressed through the survey, tentatively confirm that they recognize this negative practice and they do not approve of it to a large extent. This applies, above all, to the unrealistic representation of a woman's body as well as its exploitation and objectification for the purposes of creating sexual appeal. Nonetheless, the greatest paradox of this research is the results that show that depicting a beautiful girl in commercials would not be a deciding factor in consumers making a personal decision to buy a certain product, while, on the other hand, the majority of respondents thought that a product would sell better if it was advertised by a beautiful and attractive girl. Such attitudes lead to the 
conclusion that the majority of consumers and advertisers share an opinion that a woman's beauty in advertisements is a powerful means for sales, which reflects a general stereotypical attitude of society towards a woman's beauty as a predominant norm of value and success. Such a conclusion leads to a new question of whether stereotypes and sexual objectification of women are a product of society, and not advertisers, and whether, if this is the case, advertisements set socially acceptable values and attitudes themselves. Another question that arises is whether the creation of stereotypes on the representation of women in advertisements is a consequence of massive passing on of the certain advertising messages lasting for several decades, which has, through a principle of repeating the message, established certain habits in communication with consumers and acceptance of certain models of their behavior. Such questions are a good basis for undertaking new researches on this subject.

Nevertheless, regardless of 'whose fault it is' for such an attitude of society to exist, the responsibility in both cases rests with advertisers. Whether it is the case of an attitude on women's beauty as a means for sales which has naturally become ingrained in society, or whether the advertisers themselves had imposed it, the challenge of conveying positive advertising messages, which will have an effect on valuing women as persons lies in them and the responsibility to change such an attitude. Unfortunately, the fact that is frequently overlooked is that the role of marketing in society is far greater than the commercial role, and that the mission of every company should be directed to positive changes in society and creating a healthy social community, whose main section would constitute women precisely.

\section{CONCLUSION}

The consumers' attitudes that certain rules and guidelines necessarily need to exist is completely justifiable. The role of guidelines in this sense would be to remind advertisers of their social and ethical responsibility towards consumers and to make them, prior to passing on their messages, think about possible consequences every one of them could have on consumers.

This paper has analyzed a contemporary representation of women in the media advertising, as well as the way in which women perceive such advertising messages. Based on the results of different studies and making a research, we have arrived at a conclu- sion that the image of women in modern commercials is quite distorted, as well as their image in society, having in mind a great influence of advertising as a means of marketing communication. The consumers' attitudes reflected in the survey contribute to the fact that they have recognized such a negative practice and they did not approve of it to a large extent. This refers to, above all, unrealistic representation of a woman's body as well as its exploitation and objectification for the purposes of creating a sexual appeal. In this way, a general hypothesis of this research was confirmed, i.e. modern depicting of women in commercials creates a negative image of women in society from the aspects of their appearance, role and values that they have traditionally assumed, and they could have a negative effect on their perception of the self and their self-confidence.

However, the fact that the majority of respondents of this research agreed with the statement that the product would sell better if it were advertised by a beautiful and attractive girl creates a paradox, although the majority of respondents had an opinion that such a factor would not influence them to buy. Unfortunately, advertisers overly rely on a premise that 'sex sells', therefore, based on the examples from practice which were analyzed in this paper, it can be stated that the strategy of modern advertising is increasingly based on the principle 'the end justifies the means'.

Nonetheless, the purpose of Law is to change and develop the used means. It is a fact that sexual appeals in advertising messages can have a strong persuasive role (Filipović, 2013, 356), both in men and women, yet it is very important to keep their usage within certain acceptable limits. The only company that has achieved an advancement in setting the limits, is Facebook, that has within its advertising policy prohibited the use of sexual appeal both visually and verbally. In this way, Facebook has created a healthy environment for advertisers in which consumers are protected from possible negative effects of advertising. All advertisers should follow such a practice, as well as a concept of femvertising which aims to encourage women, increase their self-confidence and break stereotypes regarding them (Herby-Becker, 2016, 3).

Companies should become aware of the huge responsibility they have towards women consumers, and to take such a responsibility as a humane challenge in forming their personalities and social position that will motivate them to act in an ethical way, while creating a healthy advertising environment, and thus a healthy society. 


\section{Literature}

1. Arens. F. A., Weigold. f. M., Arens. C., (2011), Contemporary Advertising, Mc Graw Hill, New York.

2. Aysad, I. (2014) Using Woman in Advertisement as a Symbol of Sex: Cosmopolitan Magazine Example, Journal of Jasar University, No 9 Vol. 35.

3. Baird, R. T., Wahlers, G. R., Cooper K. C. (2007) Non Recognition of Print Advertising: Emotion Arousal and Gender Effects, Journal of Marketing Communications, Vol. 13, Issue 1

4. Belch, E. G., Belch, A. M. (2012) Advertising and Promotion, The McGraw-Hill Companies, 9th edition

5. Berberick, N. S. (2010) The Objectification of Women in Mass Media: Female Self Image in Misogynist Culture, The New York Sociologist, Vol. 5.

6. Brunel, F. F., Nelson, N. M., Message order effects and gender differences in advertising persuasion, Journal of Advertising, Vol. 43, Issue 3

7. Catalogue of Criteria for the Classification of Sexist Advertising, preuzeto sa: http://www. werbewatchgroup-wien.at/, dostupno: 04.07.2016.

8. Cawley, J., Avery, R., Eisenberg, M. (2011) The Effect of Advertising and Deceptive Advertising on Consumption: The Case of Over-the Counter Weight Loss Products, Cornell University

9. Cramphorn, F. M. (2011) Gender Effects in Advertisement, Journal of Advertising Research, Volume: 53 issue: 2, page(s): 147-170

10. Crisan, R., Pop, A. (2013) Women as Advertising Target Versus Women as an Advertising Tool, Academica Science Journal, Economica Series, No. 2 (3)

11. Filipović J., (2013) Pregled marketinških apela i njihova uloga u strategiji razvoja uspešne markentiške komunikacije, Marketing, vol. 44. br. 4.

12. FemCities Conference (2012) Ending Gender Stereotyping and Sexist Portrayals in Advertising, City of Vienna, Department for the Promotion and Coordination of Women's Issues

13. Ferrier, A., Fleming, J. (2014) The Advertising EffectHow to Change Behavior, Oxford University Press

14. Florin, D., Callen, B., Mullen, S., Kropp, J. Emotional Connection Can Build Strong Brands Seven Ways, Hiebing

15. Furnham, A., Paltzer, S. (2010) The Portrayal of Men and Women in Television Advertisements: An Updated Review of 30 studies published since 2000, Scandinavian Journal of Psychology, University College London, UK

16. Gallagher, J. (2016) Psychological Effects of Fitness Advertising on Female Collegiate Athletes, Elon Journal of Undergraduate Research in Communications, Vol. 6, No. 2.

17. Hayko, G. (2010) Effects of Advertising on Society: A Literary Review, HOHONU, Volume 8
18. Becker-Herby, E. (2016), The Rise of Femvertising: Authentically Reaching Female Consumers, University of Minnesota- Twin Cities School of Journalism and Mass Communication

19. Hobbs, R., Broder, Sh., Pope, H., Rowe, J. (2006) How Adolescent Girls Interpret Weight-loss Advertising, Health Education Research, Oxford University Press

20. Kanuk, L., Shiffman, L. (2011) Ponašanje potrošača (Consumer Behavior), Zagreb

21. Kimmel, M. S., Hearn, J., Connell, H. (2005) Handbook of Studies on Man and Masculinity, SAGE

22. Klein, M. K. (2013) Why Don't I Look Like Her? The Impact of Social Media on Female Body Image, Claremont McKenna College

23. Maričić, B., Radulović, D., (2013), Uticaj osobina ličnosti i vrednosti na prihvatanje advertajzing poruka od strane žena potrošača, Marketing, Vol.44. 5-13.

24. Moriarty, Mitchell, Wells, (2009), Advertising, Principles \& Practice, Pearson International Edition, New Jersey.

25. Nagi, P. (2014) Projection of Women in Advertisement: A Gender Perception Study, International Journal of Managerial Studies and Research (IJMSR) Volume 2, Issue 9

26. Ognjanov, G. (2009), Integrisane marketinške komunikacije, Ekonomski fakultet, Beograd.

27. Pardun, J. C. (2014) Advertising and Society, The Second Edition, John Wiley \& Sons, Inc.

28. Sheehan, K. (2014) Controversies in Contemporary Advertising, SAGE Publications, Inc, London, United Kingdom

29. Terence, A. Sh. (2008) Advertising, Promotion and Other Aspects of Integrated Marketing Communications, South-Western Cengage Learning

30. The Chartered Institute of Marketing (2009) How to define your unique selling proposition, Berkshire, UK

31. Torlak, N. (2010) Zloupotreba žena u oglasima, Projekat borba protiv seksualnog i rodno zasnovanog nasilja, Uprava za rodnu ravnopravnost, Ministarstvo rada i socijalne politike, Beograd

32. Zimmerman, A., Dahlberg, J. (2008) The Sexual Objectification of Women in Advertising: A Contemporary Cultural Perspective, Journal of Advertising Research, Buffalo, New York

33. Živković, R. (2011) Ponašanje potrošača, Univerzitet Singidunum, Beograd

\section{Internet sources}

- http://www.dailymail.co.uk/news/article-2856961/ Coca-cola-criticized-sexist-new-ad-campaignfeatures-naked-women-covered-dripping-milk.html, Retrieved: 04.07.2016. 
- http://www.eonline.com/news/602804/coca-cola-ssexist-milk-ads-won-t-be-used-for-their-nationalcampaign-following-backlash, Retrieved: 04.06.2016.

- Catalogue of Criteria for the Classification of Sexist Advertising, p. 5, Retrieved from: http://www. werbewatchgroup-wien.at/, accessed: 10.08.2017.

- Carey, 2014, Coca-Cola Under Fire For Fairlife Ad Campaign Featuring Nude Women Draped In Milk, Retrieved from: http://www.business2 community. com/, accessed: 04.07.2016.

- Fairlife's new milk adverts are unoriginal and tediosly sexist, Retrieved from: https://www.theguardian.com/, accessed: 04.07.2016.

- http://www.adwomen.org/2011/06/what-is-this-adannouncing/, Retrieved: 08.08.2017.

- https://adsoftheworld.com/media/print/playstation_ touch_both_sides, Retrieved: 08.08.2017.

- http://www.eurogamer.net/articles/2012-11-01-sonyad-compares-playstation-vita-to-a-woman-with-fourbreasts, Retrieved: 08.08.2017.

- Bergh, V. J., 2014, Trends for 2015: Perfectly Imperfect, Retrieved from: http://www.howcoolbrandsstayhot. com/, accessed: 06.07.2016.
- http://www.nicolaformichetti.com/diesel-ss-2014campaign-dieselreboot/, Retrieved: 06.07.2016.

- Klauster, 2014, Bad taste? Coca-Cola under fire for , sexist' new ad campaign which features naked women covered in dripping milk, Retrieved from: http://www. dailymail.co.uk/,accessed: 04.07.2016.

- http://news.wearetranslation.com/translationdelivers-perfectly-imperfect-campaign-for-americaneagle-outfitters/, Retrieved: 06.07.2016.

- https://www.facebook.com/policies/ads/, Retrieved: 06.07.2016.

- https://adstrategy.wordpress.com/2010/03/18/bmwsultimate-attraction/,Retrieved: 10.07.2016.

- http://www.karanovic.org/courses/mca008/ archives/1515, Retrieved: 10.07.2016.

- http://yourbusiness.azcentral.com/persuasiontechniques-beauty-product-advertising-25613.html, Retrieved: 07.08.2017.

- http://www.inquiriesjournal.com/articles/826/ appealing-to-women-an-analysis-of-printadvertisements-in-three-womens-interestmagazines, Retrieved: 30.07.2017.

\title{
Apstrakt:
}

\section{Efekti prikazivanja žena u reklamama na formiranje stavova potrošača}

\author{
Jelena Stanković, Radmila Živković, \\ Tamara Marić, Jelena Gajić
}

Uticaj reklama na formiranje društvenih stavova i ponašanje potrošača, ispoljava se na racionalnom i emocionalnom nivou. Shodno tome, efekti reklama zalaze u domene psihologije i etike, često se sukobeći sa moralnim principima društva, na kojima bi, između ostalog, komuniciranje putem reklama trebalo da se zasniva. Stereotipno prikazivanje žena u reklamama, kao domaćice, uspešne poslovne žene bez porodice, ili samo kao ukrasnog objekta, svakodnevno se pronalaze u svim oblicima oglašavanja, od bilborda i televizijskih reklama, do reklama na internetu. Paradoks, u kome se žene masovno pojavljuju u reklamama bez neke jasne veze sa proizvodom, nameće kao cilj ovoga rada sledeća pitanja: da li je učestalo prika- zivanje žena u reklamama zaista i potrebno, da li je uopše poželjno, i da li sugerisani model ženske lepote, koji se na ovaj način promoviše, ipak predstavlja najmoćnije "sredstvo" prodaje. Ukoliko to jeste najmoćnije sredstvo, da li je moguće pomiriti dve suprotne pojave koje proizilaze iz te činjenice - društvenu, koja ženu, na ovakav način, stavlja u negativan kontekst, loše utiče na njeno lično zadovoljstvo i samopouzdanje, a i kosi se sa principima morala i etike, i marketinšku, koja ima za cilj privlačenje potrošača, samim tim menjajući njihove stavove u kupovini.

Ključne reči: reklame, žene u reklamama, stavovi potrošača, etička pitanja.

\section{Kontakt}

Jelena Stanković, jstankovic@singidunum.ac.rs Radmila Živković, rzivkovic@singidunum.ac.rs Tamara Marić, tamara.maric.11@singimail.rs Jelena Gajić, jgajic@singidunum.ac.rs 